\title{
Effect of dietary $\beta-1,3-g l u c a n$ on resistance to white spot syndrome virus (WSSV) in postlarval and juvenile Penaeus monodon
}

\author{
Cheng-Fang Chang ${ }^{1,2, *}$, Mao-Sen $\mathrm{Su}^{2}$, Houng-Yung Chen ${ }^{1}$, Chu-Fang $\mathrm{Lo}^{3}$, \\ Guang-Hsiung Kou ${ }^{3}$, I-Chiu Liao ${ }^{4}$ \\ ${ }^{1}$ Institute of Marine Biology, National Sun Yat-Sen University, Kaohsiung, Taiwan, ROC \\ ${ }^{2}$ Tungkang Marine Laboratory, Taiwan Fisheries Research Institute, Tungkang, Pingtung, Taiwan, ROC \\ ${ }^{3}$ Department of Zoology, National Taiwan University, Taipei, Taiwan, ROC \\ ${ }^{4}$ Taiwan Fisheries Research Institute, Keelung, Taiwan, ROC
}

\begin{abstract}
This study evaluated the effectiveness of dietary incorporation of $\beta$-1,3-glucan from Schizophylum commune in enhancing the resistance of postlarval (PL15) or juvenile $(5.5 \pm 0.5 \mathrm{~g})$ Penaeus monodon to white spot syndrome virus (WSSV). The shrimp were fed experimental diets with $\left(2 \mathrm{~g} \mathrm{~kg}^{-1}\right.$ diet) or without $\beta-1,3$-glucan for $15 \mathrm{~d}$ (postlarvae) or 10 or $20 \mathrm{~d}$ (juveniles). Following these dietary treatments, the postlarvae were challenged by immersion and the juveniles by injection using WSSV solution. After challenge with WSSV, initial mortality was significantly $(p<0.005)$ lower in all the glucan-fed groups than in the respective non-glucan control groups. In the juvenile groups, glucan supplementation for $20 \mathrm{~d}$ rather than $10 \mathrm{~d}$ significantly $(\mathrm{p}<0.005)$ enhanced survival. After the WSSV challenge, none of the control diet postlarvae or juveniles survived beyond $4 \mathrm{~d}$ and none of the $10 \mathrm{~d}$ glucan-fed juveniles survived beyond $6 \mathrm{~d}$. By contrast, some of the glucan-treated postlarvae (12.2\%) and some of the $20 \mathrm{~d}$ glucan-treated juveniles (20\%) were still alive at Day 6 . These surviving individuals were reared onwards up to $120 \mathrm{~d}$ post-challenge, at which time overall survivals were $5.5 \%$ (postlarvae) and $13.3 \%$ (juveniles) and body weights were 25 to $30 \mathrm{~g}$ (postlarvae) and 30 to $40 \mathrm{~g}$ (juveniles). Half of the surviving postlarvae and $58 \%$ of the surviving juveniles were 2-step WSSV polymerase chain reaction (PCR) negative $6 \mathrm{~d}$ after challenge. All the surviving shrimp were 2-step WSSV PCR negative $120 \mathrm{~d}$ after challenge.
\end{abstract}

KEY WORDS: $\beta$-1,3-glucan - WSSV - Postlarval and juvenile Penaeus monodon

\section{INTRODUCTION}

Since 1993, white spot syndrome (WSS) has been epizootic in various penaeid species throughout Southeast and East Asia. In the black tiger shrimp Penaeus monodon, WSS is generally characterized by obvious white spots on the carapace and appendages or generally on the inside surface of the shell. Moribund shrimp usually exhibit red discoloration, and their cumulative mortality can reach $100 \%$ within 2 to $7 \mathrm{~d}$. WSS is caused by an enveloped non-occluded rod-shaped virus

-E-mail: changch@ms3.hinet.net known as white spot syndrome virus (WSSV) (Chou et al. 1995, Wang et al. 1995), which may be closely related to rod-shaped nuclear virus (RV-PJ) of $P$. japonicus found in Japan (Inouye et al. 1994, Momoyama et al. 1994, Nakano et al. 1994, Takahashi et al. 1994), to systemic ectodermal and mesodermal baculovirus (SEMBV) of $P$. monodon in Thailand (Wongteerasupaya et al. 1995), and to hypodermal hematopoietic necrosis baculovirus (HHNBV) of $P$. chinensis in China (Cai et al. 1995),

WSSV can be detected by 1 -step or 2-step WSSV diagnostic polymerase chain reaction (PCR) (Lo et al. $1996 a, b$ 1997). The 2-step amplification is $10^{3}$ to $10^{4}$ times more sensitive than 1-step amplification (Lo et al. 
1996b). Shrimp that test positive using 1-step WSSV PCR usually die within 1 to $3 \mathrm{~d}$, while 2-step WSSV PCR positive shrimp may survive indefinitely under non-stressful conditions. Thus, captured brooders that are 2-step WSSV PCR positive may survive and even spawn successfully (Lo et al. 1996b).

In recent years, immunostimulants have been used to enhance resistance of fish and shrimp against bacterial and viral infections (Kitao \& Yoshida 1986, Oliver et al. 1986, Robertsen et al. 1990, Matsuyama et al. 1992, Raa et al. 1992, Itami et al. 1994, Sung et al. 1994, Su et al. 1995, Liao et al. 1996, Song et al. 1997). For example, dietary uptake of $\beta$-1,3-glucan increased resistance to Edwardsiella tarda and Aeromonas hydrophila in carp Cyprinus carpio (Yano et al. 1991). Itami et al. (1994) reported that dietary administration of schizophyllan, a water-soluble $\beta$-1,3-glucan derived from the fungus Schizophyllum commune and containing some $\beta-1,6$-glucosidic side chains, increased the resistance of Penaeus japonicus against vibriosis. This glucan is a known anti-tumor substance that stimulates non-specific immunity in mammals (Azuma 1987). Previous work (Su et al. 1995, Liao et al. 1996) found that $\beta$-1,3-glucan significantly enhanced postlarval, juvenile, and adult $P$. monodon resistance to Vibrio damsela and $V$. harveyi infection, but little is known about its effectiveness in enhancing immunity of shrimp to viral infections. Using a different $\beta-1,3-1,6$-glucan extracted from yeast cell walls, Song et al. (1997) revealed enhanced resistance of $P$. monodon to WSSV infection. The present study evaluated the effect of dietary intake of the $\beta$-1,3-glucan schizophyllan on the resistance of $P$. monodon to WSSV infection.

\section{MATERIALS AND METHODS}

Test diets. Two diets with $\left(2 \mathrm{~g} \mathrm{~kg}^{-1}\right)$ or without supplementation of $\beta$-1,3-glucan were prepared. This concentration was chosen because previous results (Chang et al. 1996a, Liao et al. 1996) indicated that $2 \mathrm{~g}$ $\mathrm{kg}^{-1}$ provided optimal protection. The control diet was a basal diet (Liao et di. 1996) containing a crude protein level of $46 \mathrm{~g}$ per $100 \mathrm{~g}$, a crude lipid level of $12 \mathrm{~g}$ per $100 \mathrm{~g}$, and an ash content of $8.5 \mathrm{~g}$ per $100 \mathrm{~g}$. The experimental diet consisted of the basal diet plus a supplement of $\beta-1,3$-glucan $\left(2 \mathrm{~g} \mathrm{~kg}^{-1}\right)$. This $\beta-1,3-$ glucan (schizophyllan) was obtained courtesy of the Taito Co. (Tokyo, Japan). The ingredients were mixed thoroughly and cold extruded into 0.2 to $0.5 \mathrm{~mm}$ pellets for postlarvae and 2 to $5 \mathrm{~mm}$ pellets for juveniles. Pellets were air-dried with a blower and then stored at $-10^{\circ} \mathrm{C}$ until feeding.

Feeding trials. Black tiger shrimp Penaeus monodon postlarvae (PL15) and juveniles $(5.5 \pm 0.5 \mathrm{~g})$ were arti- ficially propagated and raised at the Tungkang Marine Laboratory, Taiwan. The postlarvae were randomly divided into 2 groups of 1000 shrimp each. Each group was further divided into 4 replicates. Each replicate (250 postlarvae) was held in a 20 I rectangular plastic tank with flow-through seawater and aeration. The juveniles were randomly divided into 2 groups of 300 shrimp each and further subdivided into 3 replicates. Each replicate (100 juveniles) was held in a 2000 l circular fiberglass tank with flow-through seawater and aeration. Each experimental diet was fed to 1 group of shrimp. Each morning before feeding, all the uneaten food and debris were removed from the bottom of the tanks. The postlarvae were fed 3 times daily $(09: 00,13: 00$ and $18: 00 \mathrm{~h})$ at an initial rate of 10 to $15 \%$ of wet biomass. The ration for the juveniles was given at 3 to $5 \%$ wet weight and was divided into 2 meals (09:00 and 18:00 h). Feeding rates were adjusted thereafter according to the feeding response of the shrimp. For the postlarvae, the feeding protocol was followed for $15 \mathrm{~d}$ before challenge, and it was designed to correspond to current commercial practice by which postlarval farmers acquire and keep PL15 for $15 \mathrm{~d}$ before they are sold for pond stocking. The feeding regime for the juveniles followed Liao et al. (1996). During the experiment, water temperature ranged between 29 and $31^{\circ} \mathrm{C}$, salinity between 30 and 32 ppt and pH between 7.8 and 8.5 .

Preparation of the WSSV solution. The WSSV filtrate solution was prepared following the method of Chou et al. (1995) with minor modifications. Shell and attached epidermis were collected from frozen $\left(-80^{\circ} \mathrm{C}\right)$ black tiger shrimp from a shrimp culture pond that had been infected with WSSV. The tissues were homogenized in saline water $(1: 9 \mathrm{v} / \mathrm{v})$ at $4^{\circ} \mathrm{C}$. After centrifugation at $17345 \times g$ for $5 \mathrm{~min}$, the supernatant fluid was filtered through a $0.45 \mu \mathrm{m}$ membrane. The filtrate was used as the WSSV stock filtrate solution. In a series of immersion and injection trials, the optimal challenge dilution levels $\left(48 \mathrm{~h} \mathrm{LD}_{50}\right.$ ) of the WSSV stock filtrate were estimated as $500 \times$ for immersion of postlarvae and $20 \times$ for injection of juveniles.

Challenge tests for postlarvae. A WSSV infection challenge was performed after the postlarvae were fed test diets for $1.5 \mathrm{~d}$. The postlarvae from each of the 4 replicates of the dietary groups were randomly divided into duplicate immersion challenge and control groups of 100 postlarvae each. The WSSV stock filtrate solution was diluted 500 times in seawater and the postlarvae were immersed in $1000 \mathrm{ml}$ of this solution or $1000 \mathrm{ml}$ seawater (control groups) for $2 \mathrm{~h}$. After immersion, the postlarvae were removed to $2000 \mathrm{ml}$ glass beakers containing $1600 \mathrm{ml}$ seawater. The water temperature and salinity were 29 to $31^{\circ} \mathrm{C}$ and 30 to $32 \mathrm{ppt}$. Aeration was provided throughout the experi- 
ment. Mortality was assessed 3 times daily. Moribund shrimp were collected and tail portions were placed in $1.5 \mathrm{ml}$ microfuge tubes for storage in liquid nitrogen until used in WSSV diagnostic PCR.

Challenge tests for juveniles. Two challenge tests were conducted when the juveniles had been fed the test diets for either 10 or $20 \mathrm{~d}$. The injection solution was prepared by diluting the WSSV stock filtrate solution 20 times with saline. For each test, 20 juveniles from each replicate were challenged by intramuscular injection of the injection solution at a dose of $0.01 \mathrm{ml}$ juvenile ${ }^{-1}$. The control 'blank' group was injected with $0.01 \mathrm{ml}$ saline. After injection, the juveniles were returned to glass aquaria $(60 \times 45 \times 40 \mathrm{~cm})$ with flowthrough seawater which ranged from 29 to $31^{\circ} \mathrm{C}$ and from 30 to $32 \mathrm{ppt}$ salinity. All received the glucan-free (control) diet. The numbers of dead juveniles were recorded once every 8 to $10 \mathrm{~h}$ for $6 \mathrm{~d}$. Moribund juveniles were collected and their pleopods were excised and placed in $1.5 \mathrm{ml}$ microfuge tubes stored in liquid nitrogen until used in WSSV diagnostic PCR.

WSSV diagnostic PCR. Postlarvae and juveniles were tested before the feeding trial and challenge tests to ensure that all were initially 2 -step WSSV PCR negative, and the same 2-step WSSV diagnostic PCR (Lo et al. 1997) was used to establish absence/presence/ extent of WSSV infection after WSSV challenge. For those surviving shrimp reared onwards to $120 \mathrm{~d}$ postchallenge, organs and tissues from 10 randomly selected surviving shrimp (5 from the postlarval group and 5 from the juvenile group) were separately subjected to 2-step WSSV diagnostic PCR.

DNA was isolated from the samples as described by Lo et al. (1997), and its quality was verified with primer set $143 \mathrm{~F}-145 \mathrm{R}$ for the decapod 18S rRNA gene (template control; Lo et al. 1996a) before being used in WSSV diagnostic PCR. Following Lo et al. (1997), the outer primer set, 146F1/146R1, was used for 1-step WSSV diagnostic PCR. In each 1 -step WSSV diagnostic PCR test, DNA extracted from the muscle of a naturally WSSV-infected Penaeus monodon was used as a positive control template, and a reaction mixture containing no DNA was used as a negative (reagent contamination) control. The amplification was performed in a Thermolyne Amplitron II (Barnstead/Thermolyne Corp., Kerper Blvd, Dubuque, USA) for 1 cycle of $94^{\circ} \mathrm{C}$ for $4 \mathrm{~min}, 55^{\circ} \mathrm{C}$ for $1 \mathrm{~min}, 72^{\circ} \mathrm{C}$ for $2 \mathrm{~min} ; 39$ cycles of $94^{\circ} \mathrm{C}$ for $1 \mathrm{~min}, 55^{\circ} \mathrm{C}$ for $1 \mathrm{~min}, 72^{\circ} \mathrm{C}$ for $2 \mathrm{~min}$, plus a final 5 min extension at $72^{\circ} \mathrm{C}$ after 40 cycles. A sample of each of the completed PCR reactions $(10 \mu \mathrm{l})$ was mixed with $1 \mu \mathrm{l}$ loading buffer, subjected to electrophoresis on $1 \%$ agarose gels containing ethidium bromide at a concentration of $0.5 \mu \mathrm{g} \mathrm{ml}^{-1}$, and then visualized by ultraviolet transillumination. After completion of the first step, $10 \mu \mathrm{l}$ of the reaction mixture was added to $90 \mu$ of PCR cocktail containing the inner primer pair, $146 \mathrm{~F} 2$ and 146R2, for 2-step WSSV diagnostic PCR. The reaction was amplified for 40 cycles, and $10 \mu$ lof the final reaction mixture was used to analyze the PCR products.

Statistical analysis. The statistical significance $(p<$ 0.05 ) of differences in the shrimp survivals between the control and experimental groups in the challenge tests was evaluated by the chi-square test at each time period. Differences in survival $(p<0.05)$ between the 10 and 20 d glucan-treated juvenile groups were examined by a covariance analysis.

\section{RESULTS}

\section{Challenge tests for the postlarvae}

The survival of postlarvae fed the glucan diet for $15 \mathrm{~d}$ was significantly higher than that of basal diet control groups when challenged with WSSV (Fig. 1). Significant differences $(p<0.005)$ between the 2 groups were observed at all periods for which comparisons were made. All shrimp in the WSSV-challenged, glucan-free (control) group died by $5 \mathrm{~d}$. By contrast, mean survival in the WSSV-challenged, glucan-fed group was $12.2 \%$ on Day 6. Survivals for the non-challenged, seawater immersion control groups fed basal diet with or without glucan were 72.2 and $79.7 \%$, respectively. The WSSVchallenged survivors were cultivated further for $120 \mathrm{~d}$. By $30 \mathrm{~d}$ post-challenge, $60 \%$ of them $(7.3 \%$ of initial population) were still alive, and at $120 \mathrm{~d}, 45 \%$ (5.5\% of initial population) were still alive. Their final body weights were 25 to $30 \mathrm{~g}$. For the non-challenged, seawater immersion control groups fed basal diet with or without glucan survival was $65 \%$ at 30 d $151.9 \%$ of initial population) and $41 \%$ (32.8\% of initial population) at $120 \mathrm{~d}$, and body weights were 22 to $28 \mathrm{~g}$

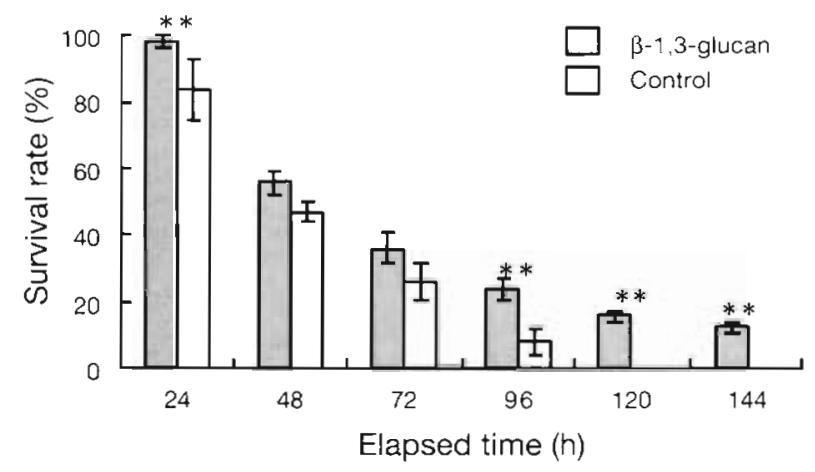

Fig. 1. Penaeus monodon. Six-day survival of postlarvae fed a diet that either contained or did not contain $2 \mathrm{~g} \mathrm{~kg}^{-1} \beta-1,3-$ glucan for $15 \mathrm{~d}$ before challenge by immersion in white spot syndrome virus (WSSV) solution. Vertical bars indicates SEM $(\mathrm{n}=4) .{ }^{*} \chi^{2}>8.3, \mathrm{df}=1, \mathrm{p}<0.005$ 


\section{Challenge tests for juveniles}

For the challenged juvenile groups fed glucan for $10 \mathrm{~d}$, a significantly better survival ( $p<0.005$ ) than the challenged basal diet controls was observed by $2 \mathrm{~d}$ post-challenge (Fig. 2A). This difference persisted for the following days. By Day 5 , all the challenged shrimp in the glucan-free, basal diet groups had died while some of the glucan-fed group still survived, although they had died by Day 6 . When fed glucan for $20 \mathrm{~d}$, mortality was also higher, but the proportion of shrimp surviving the challenge was significantly higher than it was for the $10 \mathrm{~d}$ glucan-fed group ( $<<0.005$ ) (Fig. 2B). About $40 \%$ of these challenged shrimp were still alive at $5 \mathrm{~d}$ and more than $20 \%$ were still alive at $6 \mathrm{~d}$. There was no mortality at $6 \mathrm{~d}$ for the basal diet or glucan con-

A
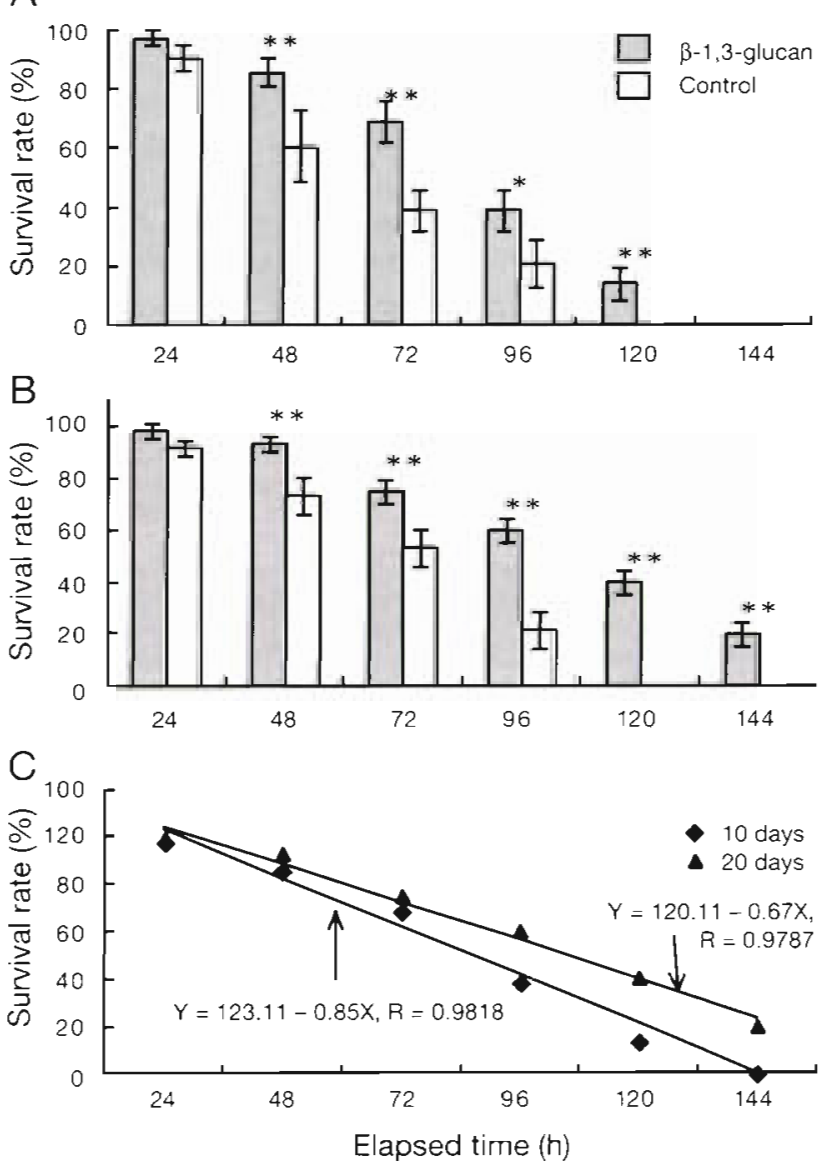

Fig. 2. Penaeus monodon. Six-day survival rates of juveniles fed on a diet that either contained or did not contain $2 \mathrm{~g} \mathrm{~kg}^{-1}$ $\beta$-1,3-glucan for (A) $10 \mathrm{~d}$ or (B) $20 \mathrm{~d}$ before being challenged with injection of white spot syndrome virus (WSSV) solution. (C) Results of the regression analysis indicate that cumulative shrimp survival rates under the 2 feeding regimes (10 and 20 d) were significantly different $(p<0.005)$. Vertical bars indicates SEM $(\mathrm{n}=3) \cdot{ }^{*} \chi^{2}>6.2, \mathrm{df}=1, \mathrm{p}<0.05, * \chi^{2}>10.3$, $\mathrm{df}=1, \mathrm{p}<0.005$ trol groups injected with saline (i.e. 100\% survival). When the WSSV-challenge survivors were reared onwards to $120 \mathrm{~d}, 75 \%$ (15\% of initial population) survived to $30 \mathrm{~d}$ post-infection, and $66.7 \%$ (about $13.3 \%$ of the initial population) survived to $120 \mathrm{~d}$, at which time body weights were 30 to $40 \mathrm{~g}$. A regression analysis (Fig. 2C) showed that the survival rate of shrimp on the $20 \mathrm{~d}$ glucan feeding regime was significantly higher ( $p<0.005$ ) than that of shrimp on the $10 \mathrm{~d}$ glucan feeding regime. For the basal diet or glucan control groups injected with saline, survival was $82 \%$ at $30 \mathrm{~d}$ post-injection and $52 \%$ at $120 \mathrm{~d}$ post-injection, by which time body weights were 25 to $30 \mathrm{~g}$.

\section{Confirmation of WSSV infection}

Although all shrimp (postlarvae and juveniles) were 2-step WSSV diagnostic PCR negative before the feeding and challenge trials, all the dead or moribund shrimp that died after WSSV challenge were found to be 1-step PCR positive. However, on Day 6 postimmersion or injection challenge, random sampling suggested that $50 \%$ of the surviving postlarvae and nearly $60 \%$ of the surviving juveniles were 2-step WSSV PCR negative (Table 1). At $120 \mathrm{~d}$, tissues from the heart, gill, stomach, midgut, hepatopancreas, abdominal muscle, lymphoid organ, pereiopods, pleopods, and haemolymph of 5 shrimp survivors each from the WSSV-challenged postlarval and juvenile groups were all found to be 2-step WSSV PCR negative.

\section{DISCUSSION}

It is commonly agreed that arthropods and other invertebrates generally do not possess immunoglobulins (Ratcliffe et al. 1985). Nevertheless, with an open circulatory system, they must have immediate, noninducible defense and coagulation mechanisms to entrap parasites and prevent blood loss upon wounding (Ratcliffe et al. 1985). These reactions are carried

Table 1. Penaeus monodon. White spot syndrome virus (WSSV) prevalence in surviving postlarvae and juvenules. Six days after challenge with WSSV, randomly selected survivors were tested for the presence of WSSV using 2-step WSSV diagnostic PCR

\begin{tabular}{|c|c|c|c|c|}
\hline \multirow{2}{*}{\multicolumn{2}{|c|}{$\begin{array}{l}\text { Tested shrimp } \\
\text { specimens }\end{array}$}} & \multicolumn{3}{|c|}{ Prevalence $(\%)$} \\
\hline & & \multirow{2}{*}{$\begin{array}{l}\text { Positive by } \\
1 \text {-step PCR }\end{array}$} & \multirow{2}{*}{$\begin{array}{l}\text { Positive only } \\
\text { by } 2 \text {-step PCR }\end{array}$} & \multirow{2}{*}{$\begin{array}{l}\text { 2-step PCF } \\
\text { negative }\end{array}$} \\
\hline Stage & No. & & & \\
\hline Postlarval & I 20 & $7(35)$ & $3(15)$ & $10(50)$ \\
\hline Juvenile & 12 & $2(17)$ & $3(25)$ & $7(58)$ \\
\hline
\end{tabular}


out primarily by the blood cells or haemocytes. It has long been recognized that the cellular defense reactions in invertebrates are most often accompanied by melanization (Soderhall 1982, Ratcliffe et al. 1985 , Soderhall et al. 1986). The key enzyme in the synthesis of the pigment melanin is phenoloxidase, which is present in arthropod blood (haemolymph) as an inactive pro-enzyme, prophenoloxidase (proPO). ProPO is activated in a stepwise process by microbial cell wall components such as the $\beta$-1,3-glucans of fungi, or the lipopolysaccharides (LPS) and peptidoglycans of Gramnegative and Gram-positive bacteria, respectively (Soderhall 1982, Soderhall et al. 1986, Johansson \& Soderhall 1989). Apart from its role in melanization, the results from several experiments have implied that components of the putative proPO activating system of arthropods stimulate several cellular defense reactions, including: (1) phagocytosis, (2) nodule formation, (3) encapsulation, and (4) haemocyte locomotion (Soderhall et al. 1986, Johansson \& Soderhall 1989). A quantitative analysis of the stimulative effects of the immunostimulants on shrimp haemocytes revealed that $\beta$-glucan had the strongest effect (Song \& Hsieh 1994). $\beta$-1,3-glucan also increases resistance to Vibrio infection in kuruma shrimp (Itami et al. 1994), adult black tiger shrimp (Liao et al. 1996) and black tiger shrimp larvae (Su et al. 1995), where post-challenge survival rates may reach over $60 \%$. Itami et al. (1994) con cluded that this increased resistance was partially due to enhancement of haemocyte phagocytic activity.

The fact that activated haemocytes also produce extra bactericidal substances, such as $\mathrm{H}_{2} \mathrm{O}_{2}$ and superoxide anion $\left(\mathrm{O}_{2}{ }^{-}\right)$, may also partially account for the increased resistance (Song \& Hsieh 1994, Sung et al. 1996). Enzymes involved in killing bacteria, such as phenoloxidase, can also be activated by the glucan (Song \& Hsieh 1994). In our study, the high rate and quick onset of mortality observed after WSSV challenge of postlarval and juvenile groups on glucan-free diets were consistent with other reports (see e.g. Chou et al. 1995, Chang et al. 1996b). However, the fact that $12.2 \%$ of the postlarvae and $20 \%$ of the juveniles survived for $6 \mathrm{~d}$ post-challenge and beyond showed that $\beta$-1,3-glucan effectively enhanced resistance to WSSV infection. On the other hand, the survival rates of the postlarvae and juveniles fed glucan were low $(<20 \%)$ and juvenile resistance appeared to develop slowly, $20 \mathrm{~d}$ feeding being required before challenge with WSSV. Thus, it appears that for shrimp the mechanism of resistance against viral infection is different from that against bacterial infection. Although bacterial resistance may be partially due to enhancement of phagocytic activity, the mechanism of viral resistance is still unknown. In any case, the results of this study clearly showed that oral administration of glucan for
$20 \mathrm{~d}$ (Fig. 2) enhanced resistance against WSSV and protected the shrimp. For more effective protection, research is needed to quantify proper doses and to elucidate the physiological factors relevant to viral resistance.

In a similar study, Song et al. (1997) investigated the effect of $\beta-1,3-1,6$-glucan on the WSSV resistance of black tiger shrimp fed intermittently with a diet containing glucan from baker's yeast Saccharomyces cerevisiae for $4.5 \mathrm{mo}$. They found that survival rates of PL66 and PL113 (i.e. juveniles and subadults) were 59 and $24 \%$, respectively, following immersion challenge with WSSV for $6 \mathrm{~h}$. While the results herein clearly demonstrate that oral administration of $\beta-1,3$-glucan for $20 \mathrm{~d}$ also enhanced viral resistance, the survival rates were generally lower than those reported in Song et al. (1997). Possibly the immersion method used by Song et al. (1997) was less stressful than the injection method employed here, but there is also evidence (e.g Chou et al. 1995) that juvenile and subadult shrimp are less susceptible to WSSV infection by immersion.

Although 40 to $50 \%$ of the surviving postlarvae and juveniles were apparently infected with WSSV (Table 1), many survived for up to $120 d$, by which time they had grown to 25 to $40 \mathrm{~g}$. By that time, all the organs sampled were 2 -step WSSV PCR negative. This suggested that possibly as a result of the glucan diet, the surviving shrimp had (1) somehow avoided infection in the first place, (2) subsequently completely eliminated the virus after infection, or (3) contained the WSSV infection and reduced the number of virus particles to below detectable levels. Further work, including time-course infection studies, should help to resolve these alternatives.

Acknowledgements. This work was in part supported by the National Science Council through a grant (NSC 87-2313-B056-005). We thank Taito Co. (Tokyo, Japan) for providing 3-1,3-glucan, and Yueh-O Shu, Mei-Lan Cheng and ChiaHung Yang of the Tungkang Marine Laboratory, Taiwan Fisheries Research Institute, for their help with laboratory work.

\section{LITERATURE CITED}

Azuma I (1987) Development of immunostimulants in Japan In: Azuma I, Jolles $G$ (eds) Immunostimulants. Japan Sci Soc Press, Tokyo, p 41-56

Cai S, Huang J, Wang C, Song X, Sun X, Yu J, Zhang Y, Yang $C$ (1995) Epidemiological studies on the explosive epidemic disease of prawn in 1993-1994. I Fish China 19: $112-117$

Chang CF, Su MS, Chen HY, Liao IC (1996a) Vibriosis resistance and wound healing enhancement of Penaeus monodon by beta-1,3-glucan from Schizophyllum commune and polyphosphorylated l-ascorbic acid. J Taiwan Fish Res 4(1):43-54 (in Chinese with English abstract)

Chang PS, Lo CF, Wang YC, Kou GH (1996b) Identification of 
white spot syndrome associated baculovirus (WSBV) target organs in shrimp penaeus monodon by in situ hybridization. Dis Aquat Org 27:131-139

Chou HY, Huang CY, Wang CH, Chiang HC, Lo CF (1995) Pathogenicity of a baculovirus infection causing white spot syndrome in cultured penaeid shrimp in Taiwan. Dis Aquat Org 23:165-173

Inouye $\mathrm{K}$, Miwa $S$, Oseko N, Nakano H, Kimura T, Momoyama K. Hiraoka M (1994) Mass mortalities of cultured kuruma shrimp Penaeus japonicus in Japan in 1993: electron microscopic evidence of the causative virus. Fish Pathol 29(2):149-158

Itami T, Takahashi Y, Tsuchihira E, Igusa $H$, Kondo M (1994) Enhancement of disease resistance of kuruma prawn Penaeus japonicus and increase in phagocytic activity of prawn hemocytes after oral administration of $\beta-1,3$-glucan (schizophyllan). The Third Asian Fisheries Forum. Asian Fisheries Society, Manila, p 375-378

Johansson MW, Soderhall K (1989) Cellular immunity in crustaceans and the proPO system. Parasitol Today 5:171-176

Kitao T, Yoshida Y (1986) Effect of an immunopotentiator on Aeromonas salmonicida infection in rainbow trout (Salmo gairdneri). Vet Immunol lmmunopathol 12:287-296

Liao IC, Su MS, Chang CF, Her BY, Kojima T (1996) Enhancement of the resistance of grass prawn Penaeus monodon against Vibrio damsela infection by beta-1,3glucan. J Fish Soc Taiwan 23:109-116

Lo CF, Leu JH, Ho CH, Chen $\mathrm{CH}$, Peng SE, Chen YT, Chou $\mathrm{CM}$, Yeh PY, Huang $\mathrm{CJ}$, Chou HY, Wang $\mathrm{CH}$, Kou GH (1996a) Detection of baculovirus associated with white spot syndrome (WSBV) in penaeid shrimps using polymerase chain reaction. Dis Aquat Org 25:133-141

Lo $\mathrm{CF}$, Ho CH, Peng SE, Chen CH, Hsu HE, Chiu YL, Chang CF, Liu KF, Su MS, Wang CH, Kou GH (1996b) White spot syndrome associated virus (WSBV) detected in cultured and captured shrimp, crabs and other arthropods. Dis Aquat Org 27:215-225

Lo CF, Ho CH, Chen CH, Liu KF, Chiu YL, Yeh PY, Peng SE, Hsu HE, Liu HC, Chang CF, Su MS, Wang CH, Kou GH (1997) Detection and tissue tropism of white spot syndrome baculovirus (WSBV) in captured brooders of Penaeus monodon with a special emphasis on reproductive organs. Dis Aquat Org 30:53-72

Matsuyama H, Mangindaan REP, Yano T (1992) Protective effect of schizophyllan and scleroglucan against Streptococcus sp. infection in yellowtail (Seriola quinqueradiata). Aquaculture 101:197-203

Momoyama $\mathrm{K}$, Hiraoka $\mathrm{M}$, Nakano $\mathrm{H}$, Koube $\mathrm{H}$, Inouye $\mathrm{K}$, Oseko N (1994) Mass mortalities of cultured kuruma shrimp, Penaeus japonicus, in Japan in 1993: histopathological study. Fish Pathol 29(2):141-148 (in Japanese)

Nakano $\mathrm{H}$, Koube $\mathrm{H}$, Umezawa S, Momoyama $\mathrm{K}$, Hiraoka $M$, Inouye $K$, Oseko $N$ (1994) Mass mortalities of cultured kuruma shrimp, Penaeus japonicus, in Japan in 1993: epizootiological survey and infection trails. Fish Pathol 29(2): 135-139 (in Japanese with English abstract)

Oliver G, Eaton CA, Campbell N (1986) Interaction between

Editorial responsibility: Timothy Flegel,

Bangkok, Thailand
Aeromonas salmonicida and peritoneal macrophages of brook trout (Salvelinus fontinalis). Vet Immunol Immunopathol 12:223-234

Raa J, Roerstad G, Engstad R, Robertsen B (1992) Thé use of immunostimulants to increase resistance of aquatic organisms to microbial infections. In: Shariff IM, Subasinghe RP, Arthur JR (eds) Diseases in Asian aquaculture. Fish Health Section, Asian Fish Soc, Manila, p 39-50

Ratcliffe NA, Rowley AF, Fitzgerald SN, Rhodes CP (1985) Invertebrate immunity - basic concepts and recent advances. Int Rev Cytol 97:183-349

Robertsen B, Rorstad G, Engstad R, Raa J (1990) Enhancement of non-specific disease resistance in Atlantic salmon, Salmon salar L., by a glucan from Saccaromyces cerevisiae cell walls. J Fish Dis 13:391-400

Soderhall K (1982) Prophenoloxidase activating system and melanization - a recognition mechanism of arthropods: a review. Dev Comp Immunol 6:601-611

Soderhall K, Smith VJ, Johansson MW (1986) Exocytosis and uptake of bacteria by isolated haemocyte populations of two crustaceans: evidence for cellular co-operation in the defence reactions of arthropods. Cell Tissue Res 245:43-49

Song YL, Hsieh YT (1994) Immunostimulation of tiger shrimp (Penaeus monodon) hemocytes for generation of microbiocidal substances: analysis of reactive oxygen species. Dev Comp Immunol 18:201-209

Song YL, Liu JJ, Chan LC, Sung HH (1997) Glucan-induced disease resistance in tiger shrimp (penaeus monodon). Fish Vaccinol 90:413-421

Su MS, Liu KF, Chang CF, Liao IC (1995) Enhancement of grass prawn Penaeus monodon postlarvae viability by beta-1,3-glucan from Schizophyllum commune. J Taiwan Fish Res 3:125-132 (in Chinese with English abstract)

Sung $H H$, Ken GH, Song YL (1994) Vibriosis resistance induced by glucan treatment in tiger shrimp (Penaeus monodon). Fish Pathol 29:11-17

Sung HH, Yang YL, Song YL (1996) Enhancement of microbicidal activity in the tiger shrimp Penaeus monodon via immunostimulation. J Crustac Biol 16:278-284

Takahashi $Y$, Itami T, Kondo M, Maeda M, Fujii R, Tomonaga S, Supamattaya K, Boonyaratpalin S (1994) Electron microscopic evidence of bacilliform virus infection in kuruma shrimp (Penaeus japonicus). Fish Pathol 29(2):121-125

Wang CH, Lo CF, Leu JH, Chou CM, Yeh PY, Chou HY, Tung MC, Chang CF, Su MS (1995) Purification and genomic analysis of baculovirus associated with white spot syndrome (WSBV) of Penaeus monodon. Dis Aquat Org 23: $239-242$

Wongteerasupaya C, Vickers JE, Sriurairatana S, Nash GL, Akarajamorn A, Boonsaeng V, Panyim S, Tassanakajon A, Withyachumnarnkul B, Flegel TW (1995) A non-occluded. systemic baculovirus that occurs in cells of ectodermal and mesodermal origin and causes high mortality in the black tiger prawn Penaeus monodon. Dis Aquat Org 21:69-77

Yano T, Matsuyama H, Mangindaan REP (1991) Polysaccharide-induced protection of carp, Cyprinus carpio L., against bacterial infection. J Fish Dis 14:577-582

Submitted: September 18, 1998; Accepted: January 1, 1999

Proofs received from author(s): May 21, 1999 